\title{
USING DIFFERENT TYPES OF SOYBEAN MEALS AS PROTEIN SOURCES REPLACE FISHMEAL IN DIETS FOR MONOSEX NILE TILAPIA (Oreochromis niloticus). Abdel-Warith, A. A. \\ Dept. of Animal Production, Fac. of Agric., Al-Azhar Univ., Nasr City, Cairo, Egypt.
}

\begin{abstract}
This study was conducted to determine the nutritional value of different sources of soybean meal as partial replacement of fish meal component of practical diets for Nile tilapia (Oreochromis niloticus) fingerlings (mean initial fish weight $22.62 \pm 0.32 \mathrm{~g}$ ). Five tested diets based on a herring fish meal (HFM) as a reference protein source were used in this study. The experimental diets were designed to contain $50 \%$ replacement of total protein content as fish meal in the control diet $(100 \%$ fish meal) which equal to $61 \%$ of fish meal protein. All diets were nearly isonitrogenous and isocaloric in gross terms. The results showed that there were significant differences $(\mathrm{P}<0.05)$ among the final average body weight of fish at the end of the 12 weeks feeding trial. The mean final body weight of fish fed control diet, soy protein concentrate (SPC), soy flour (SF), soybean meal (SBM) and full fat soybean (FFSB) was 113.71, 100.78, 91.21, 89.97 and 85.32g, respectively. The poorest response was observed for fish fed FFSB containing diet. Similar trends were also observed in specific growth rate (SGR), feed conversion ratio (FCR), protein efficiency ratio (PER) and feed intake (FI). The viscera-somatic index (VSI) did not reflex significant differences for all fish fed the experimental diets, while results of hepatosomatic index $(\mathrm{HSI})$ showed significant differences $(\mathrm{P}<0.05)$ among treatments. Economic analysis showed the possibility of using different sources of soy as an alternative protein source in monosex Nile tilapia feed. Diets contained $50 \%$ of total protein from SBM, FFSB followed by SF provided the best economic efficiency of fish weight gain, while diets containing FM and SPC resulted in less economic efficiency because of the high in the price of feed cost per $\mathrm{kg}$ weight gain. The results of the present study indicated that, the monosex Nile tilapia can be fed plant protein sources (soybeans) to replace $50 \%$ of total dietary protein or $61 \%$ of fish meal in the diets without compromising growth and feed conversion and no mortality was observed during the experimental period and the overall health appearance of fish was normal.

Keywords: Monosex Nile tilapia, Different type of soy, Fish meal, Soy protein concentrate, Economic analysis.
\end{abstract}

\section{INTRODUCTION}

Intensive fish culture requires diets with high protein content. Fishmeal is widely applied as the protein source for many species of fish. Because of its nutritional value, amino acids content and palatability for fish (Hardy, 1999). However, aquaculture is expanding at a rate of $11 \%$ per year while the annual global fishmeal production is constant at 6-7 million tones (Tidwell and Allan, 2001). Therefore, the research for alternative protein source is an international research priority (Hardy and Kissil, 1997). Among alternative protein sources for fishmeal, some plant proteins especially soybean meal (SBM) with different types, which appears to be the most 
appropriate because of its supply, price and amino acids profile (Storebakken et al., 2000 and $\mathrm{Ai}$ and Xie, 2005). However, soybean meal contains many anti nutrition factors (ANF) that may affect the digestion and absorption of nutrients, also might depress the growth of fish depending on treatment of soybean (Francis et al., 2001). So that, a few other soy protein sources are used in replacement of fishmeal, since appropriate processing can remove and destroyed or deactivate several ANF (Anderson and Wolf, 1995). Also, the additional of some feed enzymes like microbial phytase to tilapia diet improves the dietary phosphorus supply and reduces phosphorus excretion, also enhanced digestibility of calcium by supplementing tow sources of microbial phytase (Liebert and Portz, 2007). For instance, soy protein concentrate (SPC) is produced through aqueous ethanol or methanol extraction of defatted soy flakes, which contain high protein, approximately $65-70 \%$ crude protein which is similar to fish meal (Lusas and Riaz, 1995). This extraction can remove or deactivate most ANF, soluble carbohydrates and fiber, but not the phytic acid (Bureau et al., 1998 and Storebakken et al., 2000). Although, SPC has a relatively balanced amino acid profile for fish; yet, it is low in some essential amino acid (EAA), especially methionine. Therefore, more attention has been focused on the beneficial effect of amino acids supplementation in SPC based diets on growth performance for many fish species (Mambrini et al., 1999 and Kissil et al., 2000). Currently, soybean meal (SBM) is the most important plant protein source in fish diets. Many studies were conducted on SBM as a protein source for tilapia with variation of results (Tacon et al., 1983; Shiau et al., 1989; and Viola et al., 1994). Full fat (FFSB)and defatted soybean can replace fishmeal up to $60 \%$ in tilapia diets (Abdel-Warith, 2002). In general, SBM can supply fish diets at $67-100 \%$ of dietary protein depending on tilapia species, size of fish, content of protein in the diet, processing methods for soybean and culture condition.

The aim of the present study was to determine the potential of replacing fish meal component with four types of soybean products as a protein sources in diets for Nile tilapia (Oreochromis niloticus). SPC, SF, SBM and FFSB were compared at similar inclusion level with control diet fed to tilapia to investigate the effect of partial substitution of fishmeal by these products of soya on growth performances and feed utilization for Nile tilapia.

\section{MATERIALS AND METHODS}

\section{Experimental diets}

Five experimental diets were formulated to contain a variable proportion of SPC, SF, SBM and FFSB to partially replace the fishmeal component of the diet. All of these ingredients were obtained from the local market, except SPC which was obtained from Central Soya Company, Denmark.

Chemical composition for all ingredients of crude protein, lipid, ash and crude fiber were described in table (1). All diets were designed to be in gross nutrient terms and were adjusted at appropriate levels to contain 30\% crude protein, $11-13 \%$ lipid and $439-457 \mathrm{Kcal}$ gross energy / 100g diet. Table (2) shows the proximate feed formulation and composition of the 
experimental diets. A control diet based on herring fishmeal (HFM) served as the reference source of dietary protein used to be substituted with different types of soybean. Wheat bran was also included as bulk filler component.

Table (1): Chemical composition (\%DM) of herring fish meal (HFM), soy protein concentrate (SPC), soy flour (SF), soybean meal (SBM), full fat soy (FFSB), wheat bran and yellow corn used in formulated diets fed to monosex Nile tilapia.

\begin{tabular}{lcccccc}
\hline Items & DM & CP & EE & Ash & CF & NFE \\
\hline Herring fish meal (HFM) & 93.10 & 72.30 & 9.80 & 13.62 & 0.80 & 3.48 \\
Soy protein concentrate (SPC) & 95.00 & 66.54 & 0.92 & 6.51 & 4.28 & 21.75 \\
Soy flour (SF) & 92.00 & 51.47 & 1.10 & 5.83 & 3.61 & 37.99 \\
Soybean meal (SBM) & 92.30 & 43.86 & 1.70 & 6.93 & 9.22 & 38.29 \\
Full fat soybean (FFSB) & 90.70 & 38.12 & 18.60 & 5.10 & 5.40 & 32.78 \\
Wheat bran & 88.77 & 14.60 & 3.92 & 6.37 & 12.32 & 62.79 \\
Yellow corn & 89.61 & 9.43 & 4.21 & 1.62 & 5.12 & 79.62 \\
\hline
\end{tabular}

Table (2): Formulation and chemical composition of the experimental diets fed to monosex Nile tilapia.

${ }^{1}$ Vitamins \& minerals mixture : each $1 \mathrm{~kg}$ contains : Vit A 4.8 millionlU, $D_{3} 0.8$ millionlU, $E$

\begin{tabular}{|l|c|c|c|c|c|}
\hline \multirow{2}{*}{ Diet No. } & D1 & D2 & D3 & D4 & D5 \\
\cline { 2 - 6 } Ingredients & Con. & (SPC) & (SF) & (SBM) & (FFSB) \\
\hline Fish meal & 36.00 & 14.00 & 14.00 & 14.00 & 14.00 \\
\hline Soy protein concentrate (SPC) & - & 23.40 & - & - & - \\
\hline Soy flour (SF) & - & - & 30.00 & - & - \\
\hline Soybean meal (SBM) & - & - & - & 35.00 & - \\
\hline Full fat soybean (FFSB) & - & - & - & - & 40.00 \\
\hline Wheat bran & 20.00 & 20.00 & 20.00 & 20.00 & 20.00 \\
\hline Yellow corn & 20.00 & 20.00 & 20.00 & 18.00 & 17.00 \\
\hline Corn oil & 6.00 & 8.00 & 8.00 & 7.00 & 3.00 \\
\hline Dicalcium phosphate & 1.5 & 2.00 & 2.50 & 2.00 & 2.00 \\
\hline Vit. \& Min. mix. ${ }^{1}$ & 2.00 & 2.00 & 2.00 & 2.00 & 2.00 \\
\hline Binder ${ }^{2}$ & 2.00 & 2.00 & 2.00 & 2.00 & 2.00 \\
\hline Cellulose & 12.5 & 8.60 & 1.50 & & \\
\hline Proximate composition\% (on DM basis) & \multicolumn{3}{|c|}{} & & \\
\hline DM & 91.62 & 92.73 & 91.88 & 91.54 & 90.77 \\
\hline CP & 30.37 & 30.32 & 30.19 & 29.86 & 29.85 \\
\hline CEE & 11.25 & 11.47 & 12.06 & 11.43 & 12.92 \\
\hline CF & 6.97 & 6.82 & 6.31 & 7.86 & 7.10 \\
\hline Ash & 11.42 & 10.98 & 10.26 & 11.21 & 11.51 \\
\hline NFE ${ }^{3}$ & 39.99 & 40.41 & 41.18 & 39.64 & 38.62 \\
\hline GE kcal/100g ${ }^{4}$ & 445.86 & 449.42 & 457.50 & 443.21 & 439.62 \\
\hline ME kcal/100g ${ }^{5}$ & 272.42 & 274.67 & 280.11 & 271.31 & 281.57 \\
\hline P/E ratio ${ }^{6}$ & 111.48 & 110.39 & 107.78 & 110.06 & 106.01 \\
\hline
\end{tabular}

$4 \mathrm{~g}, \mathrm{~K} 0.8 \mathrm{~g}, \mathrm{~B}_{1} 0.4 \mathrm{~g}, \mathrm{~B}_{2} 1.6 \mathrm{~g}, \mathrm{~B}_{6} 0.6 \mathrm{~g}, \mathrm{~B}_{12} 4 \mathrm{~g}$, Pantothenic acid $4 \mathrm{~g}$, Nicotinic acid $8 \mathrm{~g}$; Folic acid 400mg; Biotin 20mg; Choline chloride 299g; Copper 4g; Iron 12g; Manganese 22g; Zinc 22g; and Selenium 0.04g.

${ }^{2}$ Carboxymethyl Cellulose

${ }^{3}$ Nitrogen free extract (NFE) $=100-(C P+E E+C F+A s h)$.

${ }^{4}$ Gross energy (GE) was calculated as $5.65,9.45$ and $4.2 \mathrm{Kcal} / \mathrm{g}$ for CP, EE, and NFE, respectively according to Hepher et al., 1983.

${ }^{5}$ Metabolizable energy (ME) was calculated as $3.9,8.0$ and $1.6 \mathrm{Kcal} / \mathrm{g}$ for CP, EE, and NFE respectively NRC (1993).

${ }^{6} \mathrm{Mg}$ protein /Kcal ME. 


\section{Feeding regime and Experimental system}

Fish were fed for one week to acclimation for each test diet, the experimental system and to free their gastrointestinal tract from the preexperimental diet until the feeding response was uniform. Fish were fed twice daily by hand at a rate of $3 \%$ body weight per day for all experimental period (12 weeks). The fish were weighed bi-weekly. The feeding trail was conducted in the fish experimental station belonging to Department of Animal Production, Faculty of Agriculture, Al-Azhar University, Nasr City, Cairo, Egypt. The experimental fish were stocked in ten rectangular fiberglass tanks $(1 \times 2 \times 0.5 \mathrm{~m})$ supplied with dechlorinated tap water through a closed water recycling system provided with mechanical and biological filter tanks. Tank water was aerated continuously using an air compressor. Dissolved oxygen was determined using an oxygen meter (Jenway model 9070) monitored and remained at acceptable levels throughout the experimental period. The range for dissolved oxygen was 5-7.5 mg/l. Water temperature was measured using the same apparatus and maintained at $27 \pm 1^{\circ} \mathrm{C}, \mathrm{pH}$ was determined via a pH meter (Jenways model), ammonia $\left(\mathrm{NH}_{3}\right)$, nitrite $\left(\mathrm{NO}_{2}^{-}\right)$, nitrate $\left(\mathrm{NO}_{3}{ }_{3}\right)$ and total ammonia was 0.01-0.03 mg/l, $\mathrm{pH} 6.5-7.5 \mathrm{NO}_{2}$ and $\mathrm{NO}_{3}$ were 0.007 and $0.28 \mathrm{mg} / \mathrm{l} \mathrm{respectively.}$

\section{Experimental fish}

Hormone treated monosex all males Nile tilapia (O. niloticus) were obtained from Abbassa Fish Hatchery, Abohammad, Sharkia Governorate, Egypt. After one week adaptation period, a number of fish representing about $25 \%$ of the population was netted from the stock tank and weighed individually to obtain the nearest average initial weight of the experimental fish. A total number of 200 fingerlings with initial average body weight (22.62g) were randomly distributed among 10 fibreglasses at 20 fish per tank; two replicate tanks were used for each experimental diet. All experimental fish were weighed biweekly in order to adjust the daily feed amount. Thirty fish from the beginning were stored frozen $\left(\right.$ at $-20^{\circ} \mathrm{C}$ ) to determine initial body composition. Six fish were randomly collected from each treatment at the end for determination of whole body proximate composition. All experimental fish were apparently healthy.

\section{Proximate analysis}

Proximate analysis of ingredients, diets and whole body of fish were performed according to AOAC (1990) for crude protein (CP\%) ether extract (EE\%) ash (\%), dry matter (DM) and crude fiber (CF\%) (Table 1).

\section{Statistical analysis}

All data were analyzed by using one-way analysis of variance (ANOVA). Duncan's Multiple Range test (1955) was used to compare between treatment means. Differences were considered significant at 0.05 probability level. All statistical analysis were performed using the SAS program (Statistical Analysis System, 1999). 


\section{RESULTS AND DISCUSSION}

\section{Growth performance}

The growth performance and feed utilization data for monosex Nile tilapia (Oreochromis niloticus) fed the five experimental diets are shown in (Table 4). There were significant differences among the final average body weights of fish fed the different experimental diets. Fish fed the fishmeal based control diet demonstrated the highest mean final body weight $(113.71 \mathrm{~g})$. However, the lowest value $(85.32 \mathrm{~g})$ was observed for tilapia fed the $50 \%$ inclusion level of FFSB in the diet replacing the fishmeal component. Analysis of variance indicated that the fishmeal (FM) reflected significantly $(P<0.05)$ the heaviest weight $(113.71 \mathrm{~g})$ followed in descending significant order by SPC (D2) $100.78 \mathrm{~g}$, then SF (D3) $91.21 \mathrm{~g}$, SBM (D4) $89.97 \mathrm{~g}$ and FFSB (D5) $85.32 \mathrm{~g}$, respectively. Average of total weight gain during the whole experimental period were found to be $91.21 \mathrm{~g}$ for control diet fed to monosex Nile tilapia, while fish fed the different sources of soy SPC, SF, SBM and FFSB demonstrated $77.61,68.66,67.46$ and $62.96 \mathrm{~g}$, respectively. Similar results have been obtained by Olli et al. (1994), they reported that the effect on weight gain of SPC was significantly different from all other soybean products.

The specific growth rate (SGR) values further supported this trend, reduced from 1.92 for the control diet to $1.75,1.66,1.65$ and $1.59 \%$ for the fish fed $50 \%$ of total protein replaced by SPC, SF, SBM and FFSB, respectively. Fish fed the $50 \%$ of SPC and SBM inclusion of plant protein source performed better than those fed on the SF, FFSB. These results were in agreement with El-Kholy et al. (2005), they found that monosex Nile tilapia fed $50 \%$ FFSB replacing fish meal gave lower results compared to the control diet. This might be due to FFSB has lower content of highly unsaturated fatty acids (HUFA) that decrease the palatability for this diet than other diets which affected feed intake.

The inclusion of alternative protein sources for the partial and total replacement of fishmeal in fish diets has been studied in previous investigations for numerous fish species. It was concluded that increasing plant protein to replace fish meal has a detrimental effect on growth rate and feed utilization above certain constraints although partial substitution is quite feasible. The feasibility of soybean in fish diets was found to depend on fish species and size as well as composition and processing techniques Liebert and Portz (2007). In this study SPC reflected the best type of feed utilization and growth performance for tilapia. These results agree with Davies et al. (1989), they reported improvement in the performance of tilapia fed the processed soy concentrate. This may be due to the better utilization of this product and its content of all essential amino acids (Table3) as well as lower content of anti-nutritional factors compared to the other type of soy. Also, Medale et al. (1998) and Mambrini et al. (1999) found similar results of SPC which can supply up to $50 \%$ of the protein in low temperature fish meal based diets for rainbow trout. In contrast, Langar (1992) reported that European sea bass fed diets with replacement fish meal by plant protein sources reduced 
growth and lowered protein utilization when SPC or soybean meal dietary incorporation exceeded $20-30 \%$ level. This might be depending on species, physiology of digestive tract and different dietary sources of plant antinutritional factors which affect digestive enzymes in the digestive system.

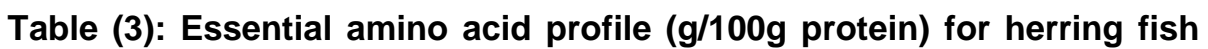
meal (HFM), soy protein concentrate (SPC), soy flour (SF), soybean meal (SBM) and full fat soy (FFSB).

\begin{tabular}{llllll}
\hline amino acids & HFM & SPC & SF & SBM & FFSB \\
\hline Arginine & 5.02 & 7.34 & 3.67 & 3.39 & 2.53 \\
Cystine & 0.81 & 0.92 & 0.75 & 0.70 & 0.34 \\
Histidine & 1.80 & 2.41 & 1.22 & 1.19 & 0.86 \\
Isoleucine & 3.41 & 4.60 & 2.14 & 2.02 & 1.60 \\
Leucine & 5.64 & 6.33 & 3.63 & 3.49 & 2.63 \\
Lysine & 5.83 & $4.34^{*}$ & 3.08 & 2.85 & 2.24 \\
Methionine & 2.27 & $0.95^{*}$ & 0.68 & 0.57 & 0.46 \\
Phenylalanine & 2.94 & 4.33 & 2.44 & 2.22 & 1.72 \\
Threonine & 3.16 & 2.85 & 1.89 & 1.78 & 1.41 \\
Tryptophan & 0.83 & $0.92^{*}$ & 0.69 & 0.64 & 0.52 \\
Valine & 4.68 & 4.34 & 2.55 & 2.02 & 2.02 \\
\hline
\end{tabular}

NRC (1993

*Russett, (1998)

\section{Feed consumption and feed utilization}

Feed conversion ratio (FCR) also differed significantly among the different groups of fish. The poorest FCR was obtained for tilapia fed the tested diet containing $50 \%$ of SBM and FFSB with values of 1.94 and 1.96 , respectively compared with fish fed other two types of soy SPC and SF with values of 1.78 and 1.86 respectively. While superior FCR were obtained for the control diet with value of 1.61 .

Protein efficiency ratio (PER) was noticeably different among treatments. Fish fed the control diet displayed the best PER (2.04) while fish receiving other diets resulted lower values 1.91, 1.79, 1.75 and 1.71 for SPC, SF, SBM and FFSB, respectively. These data show no significant differences between control diet and fish fed diets included SPC and SF.

Results of PPV\% of Nile tilapia as affected by the treatments (Table 4) revealed that the highest values of PPV were recorded with fish groups fed control and SPC diets. Averages of PPV for the control diet, and diets containing $50 \%$ of total protein of SPC, SF, SBM and FFSB decreased which were $33.03,31.47,29.57,29.17$ and $28.05 \%$, respectively without significant differences among treatments. The figures of PER had the same trend, but with significant differences $(P<0.05)$ compared with fish fed other three experimental diets. The poorer nutrient utilization by Nile tilapia fed diets containing $50 \%$ replacing fish meal by different protein sources of soy than control diet was evident with exception of SPC. They had poorer SGR, FCR, PER and PPV as a result of trypsin inhibitors (TI) activity that increases in diets containing different types of soy. These results agree with Sadiku and Jauncey (1998). 
As shown in Table (4), the highest feed intake (FI) and significant different was obtained by fish fed the control diet (D1), being $146.85 \mathrm{~g}$. However, other dietary groups pronounced a decrease in feed consumption when replaced the fish meal protein up to $50 \%$, being $138.15,127.71,130.87$ and $123.40 \mathrm{~g}$ for SPC, SF, SBM and FFSB, respectively. In contrast, Hassanen (1998) found that no significant different of feed intake for a diets containing lupin and soybean meal fed to gilthead sea beam (Sparus aurata).

Table (4): Growth performance and feed utilization values of monosex Nile tilapia fingerlings fed the experimental diets.

\begin{tabular}{|c|c|c|c|c|c|}
\hline Items $\quad$ Diet No. & D1 (Con.) & D2 (SPC) & $\begin{array}{l}\text { D3 } \\
\text { (SF) }\end{array}$ & D4 (SBM) & D5 (FFSB) \\
\hline Mean initial body weight(g) & 22.51 & 23.17 & 22.55 & 22.51 & 22.36 \\
\hline Final body weight(g) & $\begin{array}{c}113.71^{\mathrm{a}} \\
\pm 1.92\end{array}$ & $\begin{array}{c}100.78^{b} \\
\pm 2.11\end{array}$ & $\begin{array}{l}91.21^{\mathrm{c}} \\
\pm 1.74\end{array}$ & $\begin{array}{l}89.97^{c} \\
\pm 2.52\end{array}$ & $\begin{array}{l}85.32^{d} \\
\pm 1.83\end{array}$ \\
\hline Weight gain(g) & 91.20 & 77.61 & 68.66 & 67.46 & 62.96 \\
\hline Liver weight (g) & 2.92 & 2.06 & 1.72 & 1.64 & 2.01 \\
\hline Viscera weight $(\mathrm{g})$ & 1.80 & 1.50 & 1.51 & 1.40 & 1.40 \\
\hline Total feed intake(g/fish) & $\begin{array}{c}146.85^{\mathrm{a}} \\
\pm 2.31\end{array}$ & $\begin{array}{c}138.15^{\mathrm{a}} \\
\pm 1.96\end{array}$ & $\begin{array}{c}127.71^{\mathrm{b}} \\
\pm 2.53\end{array}$ & $\begin{array}{c}130.87^{b} \\
\pm 3.01\end{array}$ & $\begin{array}{c}123.40^{c} \\
\pm 2.66\end{array}$ \\
\hline $\begin{array}{l}\text { Protein consumption (g/fish) } \\
\text { FCR }^{1}\end{array}$ & $\begin{array}{r}44.60 \\
1.61^{\mathrm{b}} \\
+0.081\end{array}$ & $\begin{array}{r}40.55 \\
1.78^{\mathrm{ab}} \\
+0.095\end{array}$ & $\begin{array}{l}38.38 \\
1.86^{\mathrm{ab}} \\
+0.12\end{array}$ & $\begin{array}{r}38.62 \\
1.94^{\mathrm{a}} \\
+0.11\end{array}$ & $\begin{array}{r}36.83 \\
1.96^{\mathrm{a}} \\
+0.10\end{array}$ \\
\hline PER $^{2}$ & $\begin{array}{c}2.04^{\mathrm{a}} \\
\pm 0.115\end{array}$ & $\begin{array}{l}1.91^{\mathrm{a}} \\
0.114\end{array}$ & $\begin{array}{c}1.79^{b} \\
\pm 0.110\end{array}$ & $\begin{array}{c}1.75^{\mathrm{b}} \\
\pm 0.119\end{array}$ & $\begin{array}{c}1.71^{\mathrm{b}} \\
\pm 0.121\end{array}$ \\
\hline $\mathrm{SGR}^{3}$ & $\begin{array}{r}1.92^{\mathrm{a}} \\
\pm 0.09\end{array}$ & $\begin{array}{l}1.75^{\mathrm{b}} \\
\pm 0.10\end{array}$ & $\begin{array}{l}1.66^{c} \\
\pm 0.11\end{array}$ & $\begin{array}{l}1.65^{c} \\
\pm 0.09\end{array}$ & $\begin{array}{r}1.59^{c} \\
\pm 0.08\end{array}$ \\
\hline $\mathrm{PPV}^{4}$ & $\begin{array}{l}33.03^{a} \\
\pm 0.54\end{array}$ & $\begin{array}{l}31.47^{a} \\
\pm 0.61\end{array}$ & $\begin{array}{c}29.57^{\mathrm{ab}} \\
\pm 0.74\end{array}$ & $\begin{array}{l}29.17^{b} \\
\pm 0.65\end{array}$ & $\begin{array}{l}28.05^{b} \\
\pm 0.77\end{array}$ \\
\hline $\mathrm{HSI}^{5}$ & $\begin{array}{c}2.57^{a} \\
\pm 0.094\end{array}$ & $\begin{array}{c}2.04^{\mathrm{b}} \\
\pm 0.118\end{array}$ & $\begin{array}{c}1.89^{b} \\
\pm 0.072\end{array}$ & $\begin{array}{r}1.82^{\mathrm{b}} \\
\pm 0.02\end{array}$ & $2.36^{a} \pm 0.07$ \\
\hline $\mathrm{VSI}^{6}$ & $\begin{array}{c}1.58^{a} \\
\pm 0.034\end{array}$ & $\begin{array}{c}1.49^{a} \\
\pm 0.088\end{array}$ & $\begin{array}{c}1.65^{a} \\
\pm 0.077\end{array}$ & $\begin{array}{r}1.56^{a} \\
\pm 0.065\end{array}$ & $\begin{array}{c}1.64^{\mathrm{a}} \\
\pm 0.045\end{array}$ \\
\hline
\end{tabular}

${ }_{1}^{1}$ Feed conversion ratio (FCR): Feed intake (g)/body weight gain (g).

${ }^{2}$ Protein efficiency ratio (PER):Body weight gain (g)/protein intake (g).

${ }^{3}$ Specific growth rate (SGR): (Ln final BW $(g)$-Ln initial BW $(g)$ )/experimental period) $\times 100$

${ }^{4}$ Protein productive value (PPV) : (Retained protein $(\mathrm{g}) /$ protein consumption (g) ) $\times 100$

${ }^{5}$ Hepatosomatic index (HSI) : ( Liver weight $(\mathrm{g}) /$ fish weight $\left.(\mathrm{g})\right) \times 100$

${ }^{6}$ Viscera-somatic index (VSI): (viscera weight (g)/fish weght $\left.(\mathrm{g})\right) \times 100$

Values with the same superscript are not significantly different $(P>0.05)$.

The decreasing in feed intake could be attributed to the decrease in essential sulpher amino acid such as methionine and lysine (Table 3) which decrease in soy products less than the requirements and reduce the palatability for Nile tilapia. So that, the use of plant protein-rich ingredients may necessitate amino acid supplementation to cover the dietary amino acid profile to level that matches the essential amino acid requirements for tilapia. These are in accordance with Abdel-Hakim et al. (2006), they reported that supplementation of amino acids lysine and methionine to Nile tilapia diets improved growth performance and nutrient utilization. Hassanen (1997) who found that a mixture of protein sources with amino acids profile similar to that of requirements enhanced the growth of gilthead sea bream also he reported that there is respond positively of gilthead sea bream to amino acid 
supplementation (methionine and phenylalanine). Also, this result could be related to a poorer digestibility or metabolic utilization of dietary soy protein sources (El-Sayed et al., 2000). In addition, tilapia digestive proteases seem to be sensitive to SBMs protease inhibitors (Martinez et al. 1997). Dias et al. (1997) reported that the high replacement level of fish meal by plant protein in diets for European sea bass juveniles reduces growth performance and protein utilization. However, in the present study, processing of soybean makes it much better than other plant protein source, because it removed a lot of anti-nutrition factors by heating compared with raw seed and this processing improved a large part of the carbohydrate component by gelatinization of starch for metabolism. This was in agreement with Goda et al. (2007), they reported high growth performance and feed utilization for tilapia fed diets contained SBM and FFSB derived from dry extrusion. In this investigation, the lower growth performance and feed utilization for fish fed FFSB may be due to high plant lipid levels typically included in the diet of tilapia when used high replacement levels of FFSB. These are in accordance with Lim (2002), who found that tilapia do not tolerate as high dietary lipid as other fish (carp, trout and catfish) that utilize oil supplements quickly and efficiently.

Hepato-somatic index $(\mathrm{HSI})$ showed significant $(P<0.05)$ difference (Table 4), the values for tilapia fed control and FFSB were 2.57 and 2.36 compared with other three diets containing SPC, SF and SBM, being 2.04, 1.89 and $1.82 \%$, respectively.

The viscera-somatic index (VSI) did not reflect any trend in tilapia sampled at the end of the study. Fish fed the experimental diets revealed no significant relationship after 12 weeks, their results were 1.58, 1.49, 1.65, 1.56 and $1.64 \%$ for fish fed control, SPC, SF, SBM and FFSB, respectively.

The inferior performance of fish receiving the soybean diets compared with groups receiving fishmeal, in most studies, is possibly a result of the lower availability of nutrients and amino acids imbalance. Also, the palatability of low fishmeal diets for fish is a problem and should be addressed for even omnivorous fish such as tilapia.

\section{Fish body composition}

The whole body composition (moisture, crude protein, lipid and ash contents) of monosex Nile tilapia is shown in Table (5). There was no significant difference $(P>0.05)$ in whole body moisture.

Table (5): Chemical composition of the whole body (\% fresh weight basis) of monosex Nile tilapia fed the experimental diets.

\begin{tabular}{lcccccc}
\hline Proximate composition & Initial fish & Con. & SPC & SF & SBM & FFSB \\
\hline Moisture & 74.65 & $70.48^{\mathrm{a}}$ & $70.69^{\mathrm{a}}$ & $71.00^{\mathrm{a}}$ & $71.00^{\mathrm{a}}$ & $71.00^{\mathrm{a}}$ \\
& & \pm 0.28 & \pm 0.31 & \pm 0.65 & \pm 0.37 & \pm 0.39 \\
Protein & 12.98 & $15.52^{\mathrm{a}}$ & $15.65^{\mathrm{a}}$ & $15.66^{\mathrm{a}}$ & $15.76^{\mathrm{a}}$ & $15.51^{\mathrm{a}}$ \\
& & \pm 0.15 & \pm 0.10 & \pm 0.17 & \pm 0.11 & \pm 0.12 \\
Lipid & \multirow{2}{*}{8.07} & $9.35^{\mathrm{ab}}$ & $9.51^{\mathrm{a}}$ & $8.57^{\mathrm{c}}$ & $8.97^{\mathrm{cb}}$ & $9.78^{\mathrm{a}}$ \\
& & \pm 0.18 & \pm 0.17 & \pm 0.17 & \pm 0.16 & \pm 0.16 \\
Ash & 4.30 & $4.17^{\mathrm{a}}$ & $3.77^{\mathrm{b}}$ & $3.80^{\mathrm{b}}$ & $3.82^{\mathrm{b}}$ & $3.69^{\mathrm{b}}$ \\
& & \pm 0.72 & \pm 0.51 & \pm 0.53 & \pm 0.50 & \pm 0.52 \\
\hline
\end{tabular}

Values with the same superscript are not significantly different $(P>0.05)$. 
Moisture content was low $(70.48 \%)$ for fish fed control diet (D1) followed by fish fed diet containing different sources of soy $70.69,71.58,71.00$ and $71.00 \%$ for SPC, SF, SBM and FFSB, respectively. These results are in agreement with El-Saidy and Gaber (2005), they reported that moisture content in whole body for Nile tilapia was lower for fish fed fish meal diet than fish fed SBM diet. Protein content also reflected no significant difference $(P>0.05)$, while lipid contents showed significant differences among treatment values of whole body. The highest lipid content was observed in fish fed diet containing FFSB compared with other diets. These results are in agreement with El-Kholy et al. (2005), they reported that Nile tilapia fed $50 \%$ and $75 \%$ of FFSB and cotton seed meal showed increase in whole body lipid, while lower results were observed for fish fed diet contained SF and SBM.

Highest significant ash content was observed with fish fed fish meal diet compared with all diets containing different source of soybean while the lowest whole body ash content was observed in fish fed diet with SPC followed by FFSB, SF and SBM. These might be due to that ash content in soybean ingredients is lower than fish meal (Table 1). Also, these plant ingredients are low in phosphorus availability. These results were in agreement with Liebert and Portz (2005), they reported that scales and vertebra bone ash content of Nile tilapia was significantly increased by dietary addition of microbial phytase source to diets containing SBM. They also pointed out that this gives support to a sensitive indicator function for supply of available phosphorus and other minerals. Miranda et al. (2000) and Vielma et al. (2000) pointed out that $0.25 \%$ available phosphorus is the minimum dietary level for satisfactory bone mineralization in juvenile Nile tilapia. Furthermore, due to phytase supplementation, the availability of minerals was improved as indirectly demonstrated by increased bone and scales mineral contents.

\section{Economic evaluation}

Results in Table (6) showed economic evaluation of the tested diets including feed costs, costs of one $\mathrm{kg}$ weight gain and its ratio compared to the control diet. As presented in this table, cost of $1 \mathrm{~kg}$ of the control diet and tested diets (SPC, SF, SBM and FFSB) were 4.21, 3.75, 2.87, 2.73, and $2.64 \mathrm{LE}$, respectively. These results indicated that inclusion of different types of soybean in tilapia diets reduced the price of $1 \mathrm{~kg}$ diet to be $89.07,68.17$, 64.85 and $62.71 \%$ for the diets contained SPC, SF, SBM and FFSB compared to the price of the control diet. Feed costs to produce one $\mathrm{kg}$ weight gain were the highest for the control diet and gradually decreased to be $98.53,78.76,78.17$ and $76.25 \%$, respectively for diet containing SPC, SF, SBM and FFSB. These results indicated that tilapia diets containing different sources of soybean reduced the total feed costs, which was reflected on the total costs. However, replacing of fish meal by SPC, SF, SBM and FFSB showed slightly decrease in the growth and feed utilization parameters when soybean was included, but diet containing SPC for monosex tilapia diets seemed to be closed to the control diet so that it is not economic and reduced feed cost by $10.93 \%$ compared with fish meal (control diet). While, other diets containing SF, SBM and FFSB reduced feed costs by $31.83,35.15$, and 
$37.29 \%$, respectively. Therefore, the cost of protein ingredients is an important consideration in formulating diets for fish. In Egypt, (2006) herring fish meal price ranged between 8000 to 10000 Egyptian pound (LE) for a metric tonne compared with different type of soybean which ranged between 1800 to 2400 LE with exception of soy protein concentrate. However, most of investigations evaluated fish meal substituted in fish feeds from biological and nutritional viewpoints (Goda et al., (2007). While, little attention was given to the economic analysis for these plant protein sources. Only a few research has been evaluated economic benefit of substituting FM, these indicated that the unconventional protein sources were economical compared with fish meal as a basal protein source for fish. The advantage of using plant protein sources in tilapia diets lies not necessity in their nutrient composition, but in their availability and low prices.

Table (6): Feed costs (LE) for producing one kg weight gain by fish fed the experimental diets.

\begin{tabular}{|c|c|c|c|c|c|}
\hline ms & D1 Con. & D2 (SPC) & D3 (SF) & D4 (SBN & (FFSB) \\
\hline eed costs & 4.21 & 3.75 & & & \\
\hline & & & & & \\
\hline & & & & & \\
\hline & & & & & \\
\hline & & & & & \\
\hline & 0 & & & & \\
\hline \multicolumn{6}{|c|}{$\begin{array}{l}\text { nt used was } 8 \mathrm{LE} \text { for fish meal, } 5.5 \mathrm{LE} \text { for soy protein } \\
\text { a flour, } 1.6 \mathrm{LE} \text { for soybean meal, } 1.8 \text { for full fat soybean, } 0.60 \\
\text { for corn meal, } 6 \mathrm{LE} \text { for corn oil, } 12 \mathrm{LE} \text { for vitamins and } \\
\text { or cellulose according to market price at the time of study }\end{array}$} \\
\hline
\end{tabular}

In conclusion, the present study confirimed that monosex Nile tilapia is able to utilize plant protein based diets from different types of soybeans (SPC, SF, SBM and FFSB) up to $50 \%$ of total protein in the diets or $60 \%$ of fish meal protein. The results indicate gradual decrease in the nutritive values of diets containing different sources soybeans (depending on the type) compared with fishmeal as a control diet. Under Egyptian conditions, plant protein sources and plant by products most used as an alternative protein source for warm water fish because its quite cheap and good material for fish species rearing in Egypt. So, future investigation should focused to use these ingredients with supplementation of amino acids, phosphorus, phytase and some enzymes to improve the performances of plant protein such as oil seeds. Liebert and Portz (2007) pointed that the additional of phytase to Nile tilapia diets improves protein digestibility that may be explain the effects on enhanced protein utilization. SBM can be used in balanced diet formulations for this species with up to $60 \%$ replacement of fishmeal protein with limited decline in growth performance, but no harmful effect on health criteria was observed. Also, for economic fish culture, it can be used up to $60 \%$. Further work is required to obtain reliable digestibility data for protein, amino acids, lipid and energy components for these ingredients to realize its full potential 
in practical diets. This would necessitate investigations with various size classes of fish representing the complete production cycle.

\section{REFERENCES}

A.O.A.C. (Association of Official Analytical Chemists) (1990). Official Methods of Analysis, $15^{\text {th }}$ Edition. AOAC, Arlington, Virginia, 1298pp.

Abdel-Hakim N.F.; Kh.F. El-Kholy; A.A.Al-Azab and A.A. Abdel Warith (2006).

Effect of dietary high lysine and methionine levels on growth performance of Nile tilapia (Oreochromis niloticus) fed on diet at different frequencies. Egyptian J. Nutrition and Feeds, 9(1): 55-70.

Abdel-Warith A.A. (2002). Suitability of selected raw materials and byproducts in formulated feeds for Nile tilapia Oreochromis niloticus and African catfish Clarias gariepinus. Ph.D thesis, Fish Nutrition Unit, Dept. of Biological Sci. Plymouth Univ. UK.

Ai, Q.H. and X.J. Xie (2005). Effects of replacement of fish meal by soybean meal and supplementation of methionine in fish meal/soybean meal-based diets on growth performance of the Southern catfish (Silurus meridionalis). J. World Aquac. Soc., 36: 498-507.

Anderson, R.L. and W. Wolf (1995). Compositional changes in trypsin inhibitors, phytic acid, saponins and isoflavons related to soybean processing . J. Nutr. 125, 581S-588S.

Bureau, D.P.; A.M. Harris; and C.Y. Cho (1998). The effects of purified alcohol extracts from soy products on feed intake and growth of Chinook salmon (Oncorhynchus tshawytscha) and rainbow trout (Oncorhynchus mykiss). Aquaculture, 161, 27-43.

Davies, S.J.; N. Thomas and R.L. Bateson (1989). The nutritional value of a processed soya protein concentrate in diets for tilapia fry (Oreochromis mossambicus, Peters). The Isreali Journal of Aquaculture Bamidgeh, 41(1): 3-11.

Dias, J.; , E.F. Gomes and S.J. Kaushik (1997). Improvement of feed intake through supplementation with an attractant mix in European sea bass fed plant protein rich diets. Aquaculture Living Resource, 10: 385-389.

Duncan, D.B. (1955). Multiple range and multiple F test. Biometrics, 11: 1-42.

El-Kholy, Kh.F.; A.A. Al-Azab; A.A. Abdel-Warith and H.A. Abo State (2005). Effect of partial replacement of fish meal by full fat soybean meal or cottonseed meal supplemented with iron on growth performance and body composition of juvenile Nile tilapia (Oreochromis niloticus). Egyptian J. Nutrition and Feeds, 8(1) Special Issue: 1157-1170.

El-Saidy, D.M.S.D. and M.M.A Gaber (2005). Effectof dietary protein levels and feeding rates on growth performance, production trails and body composition of Nile tilapia, (Oreochromis niloticus) cultured in concrete tanks. Aquaculture Research, 36, 163-171.

El-sayed, A.-F.M.; I. Nmartinez and F.J. Moyano (2000). Assessment of the effect of plant inhibitors on digestive proteases of Nile tilapia using in vitro assays. Aquaculture International, 8: 403-415.

Francis, G.; H.P.S. Makkar and K. Becker (2001). Antinutritional factors present in plant-derived alternate fish feed ingredients and their effects in fish. Aquaculture, 199: 197-227.

Goda, A.M.; M.E. Wafa; E.R. El-Haroun and M. A.K. Chowdhury (2007). Growth performance and feed utilization of Nile tilapia (Oreochromis niloticus) and tilapia galilae (Sarotherodon galilaeus) fingerlings fed plant protein-based diet. Aquaculture Research, 38: 827-837.

Hardy, R.W. (1999). Aquaculture's rapid growth requirements for alternate protein sources. Feed Manage, 50: 25-28. 
Hardy, R.W. and G.W.M. Kissil (1997). Trends in aquaculture feeding. Feed Mix, 5: 31-34.

Hassanen, G.D.I. (1997). Effect of diet composition and protein level on growth, body composition and cost of production of gilthead sea bream (Sparus aurata). Egypt. J.Aquat. Biol.\& fish., 1(2): 1-18.

Hassanen, G.D.I. (1998). Lupin seed meal compared with soybean meal as partial substitutes for fish meal in gilthead sea bream (Sparus aurata). J. Agric. Mansoura Univ., 23 (1): 141-154.

Hepher, B., Liao V., Cheng S.H. and Hsieh C.S. (1983). Food utilization by red tilapia, effect of diet composition, feeding level and temperature on utilization efficiencies for maintenance and growth. Aquaculture, 3-2: 255-275.

Kissil, G.W.; I. Lupatsch; D.A. Higgs and R.W. Hardy (2000). Dietary substitution of soy and rapeseed protein concentrate for fish meal and their effects on growth and nutrient utilization in gilthead seabream (Sparus aurata L.). Aquaculture Research, 31: 595-601.

Langer, H.(1992). Effects physiologiques et métaboliques de la qualité nutritionnelle des proteins chez la teune alevin de bar (Disentrarchus labrax). Thése dr. 3éme cycle, Univ. Bretagne Occidentale, Brest, France, $136 \mathrm{p}$.

Liebert, F. and L. Portz (2005). Nutrient utilization of Nile tilapia (Oreochromis niloticus) fed plant based low phosphorus diets supplemented with graded levels of different sources of microbial phytase. Aquaculture, 248 (1-4): 111-119.

Liebert, F. and L. Portz (2007). Different sources of microbial phytase in plant based low phosphorus diets for Nile tilapia (Oreochromis niloticus) may provide different effects on phytate degradation. Aquaculture, 267 (14): 292-299.

Lim, C. (2002). Nutrient requirements of tilapia. Aquatic Animal Health Research Laboratory, USDA-ARS, Auburn, AL, USA.

Lusas, E.W. and M.N. Riaz (1995). Soy protein products : processing and use. J. Nutr., 125: 573S-580S.

Mambrini, M.; A.J. Roem; J.P. Cravedi; J.P. Lalles and S.J. Kaushik (1999). Effects of replacing fish meal with soy protein concentrate and of DLmethionine supplementation in high-energy extruded diets on the growth and nutrient utilization of rainbow trout (Oncorhynchus mykiss). J. Anim. Sci., 77: 2990-2999.

Martinez, M.I.; F.J. Alarcon; M. Diaz and A.-F.M El-Sayed (1997). Caracterizcion de las proteases alcalinas de denton comun (Dentex dentex) y tilapia (Oreochromis niloticus). In Actas VI congreso Nacional de Acuicultura. July 9-11. Cartagena (Spain), 215-220.

Médale, F.; T. Boujard; F. Vallée; D. Blanc; M. Mambrini; A. Roem and S. Kaushik (1998). Voluntary feed intake, nitrogen and phosphorus losses in rainbow trout (Oncorhynchus mykiss) fed increasing dietary levels of soy protein concentrate. Aquat. Living Rrsour., 11, 239-246.

Miranda, E.C.; A.C. Pezzato; L.E. Pezzato; C.F. Graner; G.J. Rosa and L.G.Q. Pinto (2000). Availability of calcium:phosphorus ratio in diets for Nile tilapia (Oreochromis niloticus), Rev. Bras. Zootec., 29: 2162-2171.

National Research Council (NRC), (1993). Nutrient Requirements of fish. National Academy Press, Washington, DC, $114 \mathrm{pp}$.

Olli, J.; A. Krogdahl; T.S.G.A.M. Van den Ingh and L.E. Brattas (1994). Nutritive value of four soybean products in diets for Atlantic salmon (Salmo salar, L.). Acta Agric. Scand., Sect. A. Animal Sci., 44: 50-60.

Russet, J.C. (1998). Soy protein concentrate for animal feeds. Chemurgy Rersearch Notes, SPC-T-47. 
Sadiku, S.O.E. and K Jauncey (1998). Digestibility, apparent amino acid availability and waste generation potential of soybean flour: poultry meat meal blend diets for the sharp-toothed catfish (Clarias gariepinus) fingerings. Journal of Applied Aquaculture, 8(1): 69-82.

SAS (1999). SAS/ STAT Users guide. Release, Version 6 ,03 Ed. Institute, Cary, NC, USA.

Shiau, S.Y.; C.C. Kwok; J.Y. Hwang; C.M. Chen and S.L. Lee (1989). Replacement of fishmeal with soybean meal in male tilapia $(O$. aureus $x$ O. niloticus) fingerling diets at suboptimal protein level. Journal of the World Aquaculture Society, 20: 230-235.

Storebakken, T.; S. Refstie and B. Ruyter (2000). Soy products as fat and protein sources in fish feeds for intensive aquaculture. In: Drackley, J.K. (Ed.), Soy in Animal Nutrition. Fed. Anim. Sci. Soc., Savoy, IL, USA, 127-170.

Tacon, A.G.J.; J.V. Haaster; P.B. Featherstone; K. Kerr and A.J. Jackson (1983). Studies on the utilization of full-fat soybean and solvent extruded soybean meal in a complete diet for rainbow trout, Bulletin of the Japanese Society of Scientific Fisheries, 49: 1437-1443.

Tidwell, J.H. and G.L. Allan (2001). Fish as food Aquaculture, s contribution. EMBO Rep., 2: 958-963.

Vielma, J.; T. Makinen; P. Ekholm and J. Koskela (2000). Influence of dietary soy and phytase levels on performance and body composition of large rainbow trout (Oncorhynchus mykiss) and algal availability of phosphorus load, Aquaculture, 183: 349-362.

Viola, S.; H Angeoni and E. Lahav (1994). Present limits of protein sparing by amino acid supplementation of practical carp and tilapia feeds. Israel Journal of Aquaculture Bamidgeh, 46(4): 203-211.

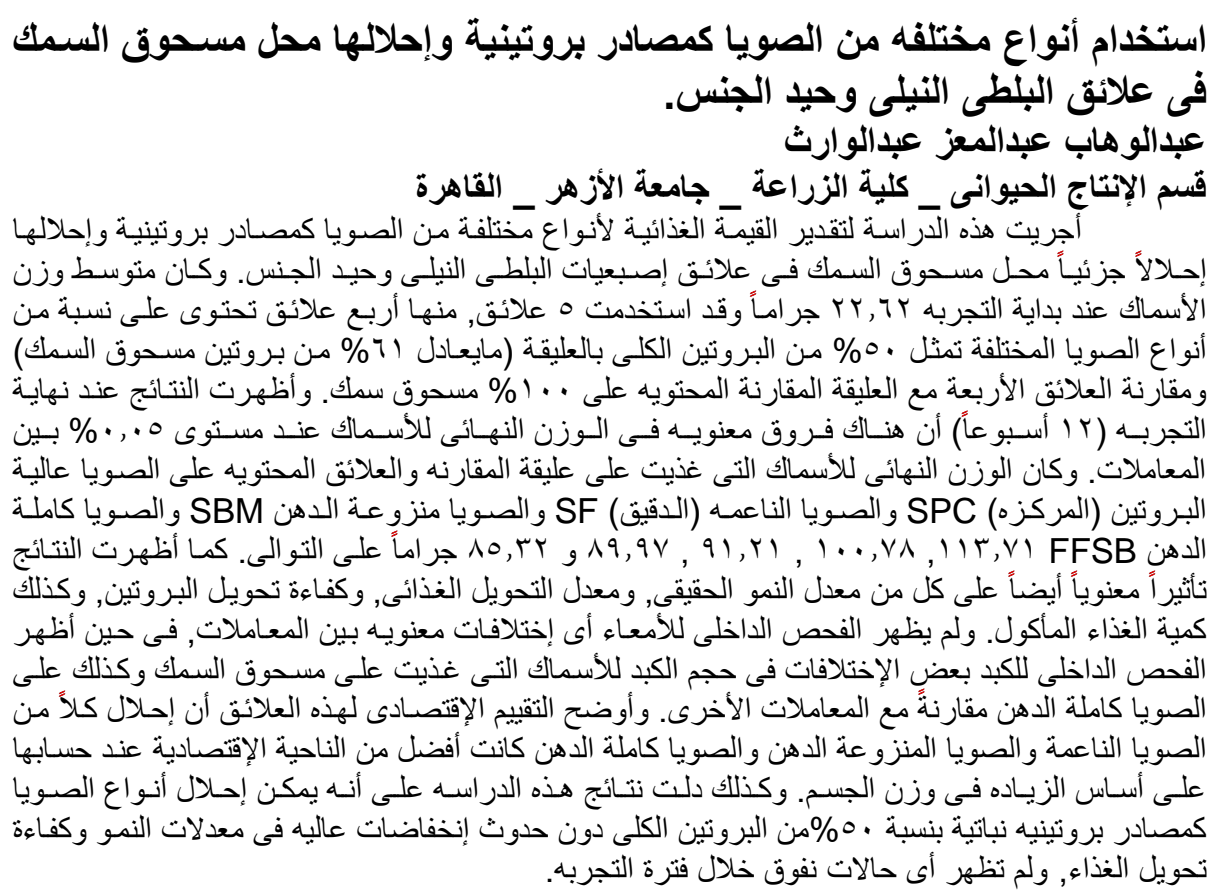

